\title{
Formation of large colonies: a defense mechanism of Microcystis aeruginosa under continuous grazing pressure by flagellate Ochromonas sp.
}

\author{
Zhen YANG, and Fanxiang $\mathrm{KONG}^{*}$ \\ State Key Laboratory of Lake Science and Environment, Nanjing Institute of Geography and Limnology, Chinese Academy \\ of Sciences, 73 East Beijing Road, Nanjing 210008, China \\ *Corresponding author: fxkong@niglas.ac.cn
}

\begin{abstract}
Induced colony formation under grazing pressure has been reported in our previous results. However, the colonies induced in these studies comprised only tens of cells which are far smaller than the naturally occurring colonies. In this work, unicellular Microcystis aeruginosa Kützing were co-cultivated with flagellate Ochromonas sp. for $50 \mathrm{~d}$ to investigate colony formation in M. aeruginosa under continuous grazing pressure. Results revealed that colonial $\mathrm{M}$. aeruginosa formed on the $10^{\text {th }} d$ under the grazing pressure of flagellate. These algal colonies resulted from the daughter cells of freshly dividing cells that failed to separate during the reproductive process. The diameters and cell numbers of the colonies increased slowly with time. Under continuous grazing pressure by Ochromonas sp. for $50 \mathrm{~d}$, the diameter of some colonies reached over $180 \mu \mathrm{m}$. Analysis showed that the extracellular polysaccharide (EPS) content and relative gas vesicle $(R G V)$ of each cell increased significantly after colony formation. However, there was no significant difference on the monosaccharide composition between unicellular and colonial M. aeruginosa. The loose aggregation of cells in the floating colonies suggests that a correlation probably exists between cell compactness and colony buoyancy.
\end{abstract}

Key words: morphological change, aggregation of algal cells, grazed-induced, relative gas vesicle, buoyancy.

Received: May 2011. Accepted: August 2011.

\section{INTRODUCTION}

Cyanobacterial blooms (blue-green algal scums) have been reported in freshwater environments world-wide. Some of these algae often lead to serious environmental problems, such as deoxygenation of underlying waters, subsequent fish kills, toxicity, foul odors, and lowered aesthetic value of affected waters (Falconer 1999; Ye et al. 2009; Zhang et al. 2011).

Microcystis aeruginosa, one of the most common species existent during cyanobacterial bloom, often occurs as large colonies with tens of thousands of cells under natural conditions. Colony formation plays an important role for the domination of this cyanobacterium in an aquatic system (Oliver 1994; Wu, and Song 2008). However, after isolation from the field and cultivation in axenic cultures in the laboratory for some generations, the colony disaggregates and develops into unicellular algae (Reynolds et al. 1981; Bolch, and Blackburn 1996), whose physicochemical properties are totally different from those of colonial algae. Thus, the results from laboratory studies using unicellular strain could not truly explain environmental phenomenon. Therefore, the mechanism of colony formation in Microcystis has to be examined to reveal the mechanism of cyanobacterial bloom.

Grazing pressure from cladocerans, a biotic factor, is an important trigger for the colony formation of green alga
Scenedesmus sp. (Hessen, and Van donk 1993). The morphological change in Scenedesmus sp. is considered as an antipredator reaction. Moreover, the infochemicals released from zooplankton are apparently responsible for this reaction (Lampert et al. 1994; von Elert, and Franck 1999; Lurling 2003a, b). The effect of grazing pressure from cladocerans on colony formation in $M$. aeruginosa has also been investigated. Although colony formation was found occasionally in some previous studies when unicellular $M$. aeruginosa was co-cultivated with cladocerans(Jang et al. 2003; van Gremberghe et al. 2009), the ability of cladocerans to induce colony formation in M. aeruginosa is uncertain (Fulton, and Paerl 1987; Hessen, and Van donk 1993; Yang et al. 2006).

Impressive progress has been obtained recently using flagellate to study the mechanism of colony formation in aquatic bacteria and algae. Hahn et al. $(2000,2004)$ revealed that bacteria could form planktonic microcolonies under the strong grazing pressure of Ochromonas sp. These microcolonies exceeded the upper size limit for ingestion by flagellates protecting them from predation. The dialysis bag batch culture experiments indicated that colony formation in bacteria is probably controlled by infochemicals released by the flagellate (Blom et al. 2010). Burkert (2001) observed some $M$. aeruginosa colonies when Ochromonas sp. accidentally entered into the compartment of $\mathrm{M}$. aeruginosa in a dialysis experiment. Our previous study also 
demonstrated that the grazing pressure from Ochromonas sp. could induce the colony formation in $\mathrm{M}$. aeruginosa (Yang et al. 2006). A filtration study showed that infochemicals released by flagellates apparently triggered the colony formation in M. aeruginosa (Yang et al. 2009a).

However, most colonies of M. aeruginosa induced in the previous studies consist of only tens of cells, which are far lesser than those occurring in the natural lake. In the present study, the unicellular M. aeruginosa is co-cultured with flagellate Ochromonas sp. for fifty days to search for large M. aeruginosa colonies under a continuous grazing pressure.

\section{MATERIALS AND METHODS}

Algae and Flagellate

M. aeruginosa ( $\mathrm{PCC} 7806,4.61 \pm 0.32 \mu \mathrm{m})$ were obtained from the Institute of Hydrobiology, the Chinese Academy of Sciences. The algae were grown in a BG-11 medium in batch culture in $250 \mathrm{~mL}$ flasks (Rippka et al. 1979) under an illumination intensity of $40 \mu \mathrm{mol}$ quanta $\mathrm{m}^{-2} \mathrm{~s}^{-1}$ provided by cool white fluorescent lamps at $25^{\circ} \mathrm{C}$ with light-dark period of 12:12 h. Cultures were shaken manually once daily. Algae in its late exponential growth phase were used in the experiment.

Flagellates Ochromonas sp. $(8.3 \pm 0.80 \mu \mathrm{m})$ were isolated from Lake Taihu, cultured in the flasks, and fed with autoclaved wheat seeds. The flagellate cultures were grown at $25^{\circ} \mathrm{C}$ under fluorescent light at an intensity of $40 \mu \mathrm{mol}$ quanta $\mathrm{m}^{-2} \mathrm{~s}^{-1}$ with a light-dark period of 12:12 h.

\section{Colony inducement experiment}

To investigate the effect of flagellate grazing on $M$. aeruginosa density and colony formation, three grazing replicates with $100 \mathrm{~mL}$ unicellular M. aeruginosa $(3 \times 106$ cell $\left.\mathrm{mL}^{-1}\right)$ and Ochromonas sp. (20000 individuals $\left.\mathrm{mL}^{-1}\right)$ were cultivated in $250 \mathrm{~mL}$ flasks at $25^{\circ} \mathrm{C}$ under fluorescent light at an intensity of $40 \mu \mathrm{mol}$ quanta $\mathrm{m}^{-2} \mathrm{~s}^{-1}$ with a lightdark period of 12:12 $\mathrm{h}$ for $50 \mathrm{~d}$. Three bottles of unicellular $M$. aeruginosa with the same densities were cultivated under the same conditions as controls. The algal (colonies were disaggregated by sonication before counting) and flagellate densities, as well as the mean diameter of $M$. aeruginosa colonies (at least 40 colonies were measured for each flask), were determined using microscope after 2 , $4,6,10,14,18,22,26,30,34,38,42,46$, and $50 \mathrm{~d}$. The mean number of algal cell per colony was obtained from algal density divided by the number of colonies.

Polysaccharide and monosaccharide assay

To eliminate the error caused by the flagellates, $M$. aeruginosa colonies were leached using a strainer with a diameter of 200 mesh before analysis.
The extracellular polysaccharide (EPS) and intracellular polysaccharide (IPS) contents of unicellular M. aeruginosa in the control flasks and colonial $M$. aeruginosa under grazing treatment for $50 \mathrm{~d}$ were analyzed at the end of the induction experiment. Samples $(10 \mathrm{~mL})$ were adjusted to $\mathrm{pH}$ 10 and incubated at $45^{\circ} \mathrm{C}$ in a water bath for $4 \mathrm{~h}$, then centrifuged at $27,500 \times \mathrm{g}$ for $15 \mathrm{~min}$. The supernates were filtered through $0.45 \mu \mathrm{m}$ membrane filters and dialyzed against deionized water to remove the interference of the presence of ions in medium cultures to assay EPS content. The algae were resuspended in $10 \mathrm{~mL}$ distilled water. After sonicating and heating at $85^{\circ} \mathrm{C}$ in a waterbath for $1 \mathrm{~h}$, they were treated with $1 \mathrm{~mL} 85 \%$ trichloracetic and centrifuged at $27,500 \times \mathrm{g}$ for $15 \mathrm{~min}$ to remove the fragments and proteins. The supernates were filtered and dialyzed as described above and were used to assay IPS content. The polysaccharide content in the dialyzed supernate was determined using glucose solutions for calibration. All polysaccharides were measured using the phenolsulfuric acid assay (Dubois et al. 1956).

Algal culture samples were centrifuged and freeze dried to obtain lyophilized algal cells. The monosaccharide composition was determined after hydrolysis of lyophilized algal cells in $2 \mathrm{~mol} \mathrm{~L}^{-1}$ trifluoroacetic acid at $120^{\circ} \mathrm{C}$ for 3 h. Neutral sugars in the hydrolysate were converted into acetylated aldononitrile derivatives for gaschromatographic analysis (Li et al. 1982). Gas-liquid chromatography was performed on an HP6890 instrument equipped with an HP$55 \%$ phenyl methyl siloxane capillary column $(30 \mathrm{~m} \times 0.25$ $\mathrm{mm}$ ID) and a flame ionization detector.

Gas vesicle volume assay

The RGV of M. aeruginosa was estimated based on the method developed by Brookes and Ganf (2001). The mean $\mathrm{RGV}$ is calculated as the difference in side scatter of cells with intact gas vesicles and that of cells with all collapsed gas vesicles under $0.8 \mathrm{MPa}$ pressure. Side scatter was measured on a single-cell basis using a flow cytometer (Benkman) with an argon laser (488 nm) as the excitation source, and RGV is measured in terms of relative side scatter unit (RSU).

\section{Data analysis}

All data were presented as mean \pm SD. Differences between the treatments and controls were analyzed by oneway ANOVA after testing for normality and homoscedasticity of the data. The level of statistical significance was considered at $p<0.05$.

\section{RESULTS}

Grazing and colony formation

Flagellate Ochromonas sp. exhibited a significant graz- 
ing ability on unicellular $M$. aeruginosa. The $M$. aeruginosa density decreased rapidly from $3.0 \times 10^{6}$ to $2.2 \times 10^{5}$ cell $\mathrm{mL}^{-1}$ after they were cultivated with flagellates for $4 \mathrm{~d}$ (Fig. 1). Meanwhile, the flagellate density increased to $1.0 \times 10^{6}$ cell $\mathrm{mL}^{-1}$. However, M. aeruginosa were not cleared completely by the flagellates, and its density in the culture increased from the $6^{\text {th }} \mathrm{d}$. On the $30^{\text {th }} \mathrm{d}$ of mix-cultivation, the $M$. aeruginosa density recovered to $3.0 \times 10^{6}$ cell $\mathrm{mL}^{-1}$, and reached to $8.05 \times 10^{6}$ cell $\mathrm{mL}^{-1}$ on the $50^{\text {th }} \mathrm{d}$. By contrast, the flagellate density remained at approximately $1.0 \times 10^{6}$ cell $\mathrm{mL}^{-1}$ after the $6^{\text {th }}$ day.

A few small colonies with several algal cell assemblages were observed on the $10^{\text {th }} \mathrm{d}$ of mix-cultivation. The diameter and cell number of colony increased with the extended mix-cultivation time (Fig. 2). On the $50^{\text {th }} \mathrm{d}$, induced colonies had a mean diameter of $68.19 \mu \mathrm{m}$ (varied from $16.45187 .24 \mu \mathrm{m}$ ) and a mean number of 377 algal cells per colony, indicating that some colonies consisted of thousands of algal cells. While $M$. aeruginosa in the control flasks were constantly dominated by unicells.

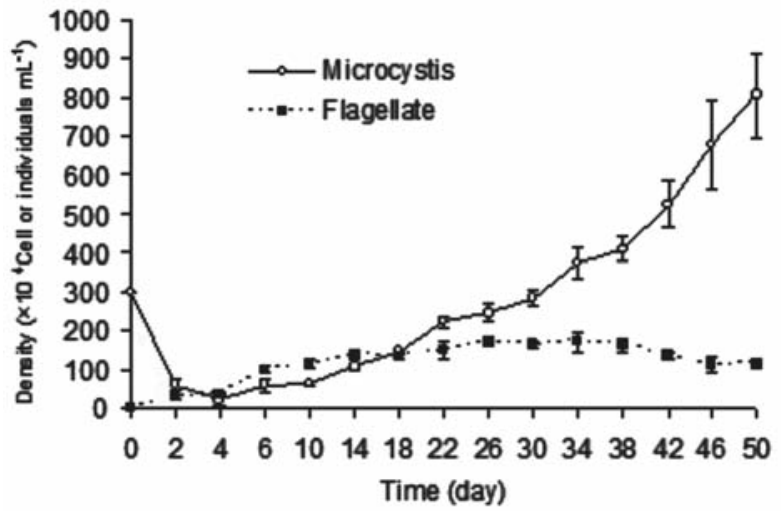

Fig. 1. Changes of cell density of $M$. aeruginosa and flagellate in the mix-cultivating system. Error bars represent $1 \mathrm{SD}(\mathrm{n}=3)$.

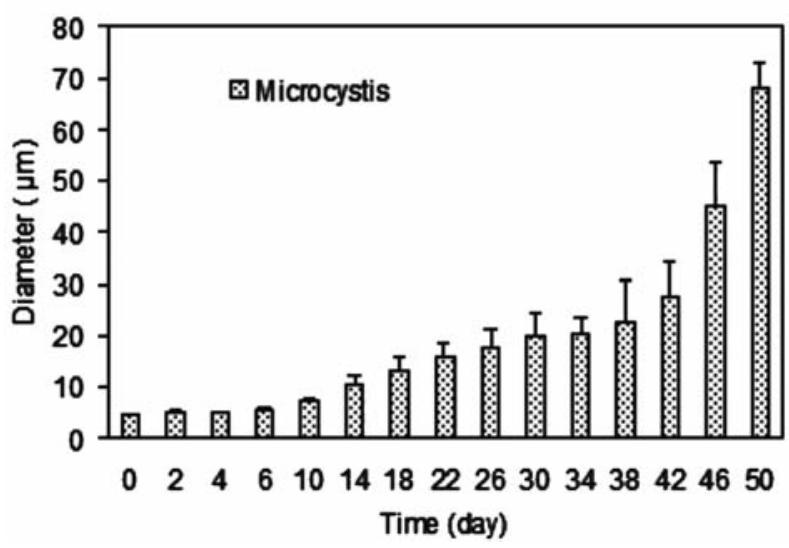

Fig. 2. Changes of mean diameter of colonial M. aeruginosa induced by flagellate. Error bars represent $1 \mathrm{SD}(\mathrm{n}=3)$.
Saccharides and buoyancy

The polysaccharide assay showed that colonial $M$. aeruginosa possess $3.36 \pm 0.33 \mathrm{pg}$ EPS per cell, significantly higher $(p<0.05)$ than that of the unicellular cells in the control flasks (Fig. 3). The IPS content in M. aeruginosa cells also increased after colony formation. However, no significant difference $(p>0.05)$ was found using one-way ANOVA.

We analyzed eight main monosaccharides in $M$. aeruginosa including glucose, galactan, mannose, fucose, xylose, ribose, rhamnose, and arabinose, after hydrolysis of polysaccharide (Tab. 1). Although there was a considerable increase in the EPS of colonial $M$. aeruginosa, no significant difference was detected on the monosaccharide composition between unicellular and colonial $M$. aeruginosa.

Interestingly, aside from the colonies that sunk at the bottom of the bottle and suspended in the culture, we also found a number of colonies that floated on the surface. The side scatter and RGV of unicellular $M$. aeruginosa control flasks were $144.83 \pm 1.43$ and $112.47 \pm 1.33$ RSU, respectively, which were significantly lower $(p<0.05)$ than those of the colonial cells (Tab. 2).

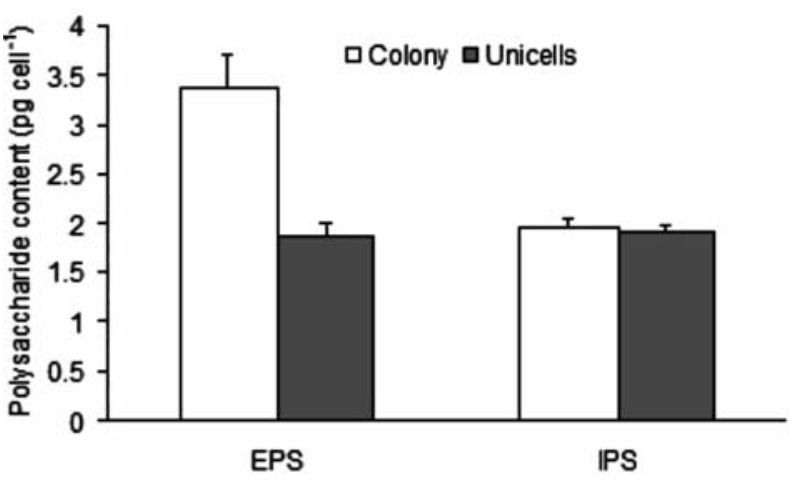

Fig. 3. Differentiation of extracellular polysaccharide (EPS) and intracellular polysaccharide (IPS) per cell between unicellular and colonial M. aeruginosa.

Tab. 1. Monosaccharides composition of unicellular and colonial M. aeruginosa.

\begin{tabular}{lcc}
\hline Monosaccharides & Unicell $(\%)$ & Colony $(\%)$ \\
\hline Glucose & 80.12 & 79.65 \\
Galactan & 9.07 & 9.38 \\
Mannose & 3.89 & 4.02 \\
Fucose & 2.34 & 2.25 \\
Xylose & 1.63 & 1.50 \\
Ribose & 1.09 & 1.20 \\
Rhamnose & 1.02 & 1.03 \\
Arabinose & 0.84 & 0.97 \\
\hline
\end{tabular}


Tab. 2. Side scatter and relative gas vesicles of unicellular, sinking and floating colonial $M$. aeruginosa.

\begin{tabular}{lccc}
\hline & $\begin{array}{c}\text { Side scatter } \\
\text { With intact gas } \\
\text { visicles }\end{array}$ & $\begin{array}{c}\text { With gas visicle } \\
\text { collapsed }\end{array}$ & RGV \\
\hline Unicell & 144.83 & 32.37 & 112.47 \\
Sinking colony & 234.03 & 43.33 & 190.7 \\
Floating colony & 299.27 & 39.73 & 259.53 \\
\hline
\end{tabular}

The side scatter and RGV in the settled colonial cells were $234.03 \pm 5.55$ and $190.7 \pm 5.01$ RSU, respectively, which were significantly less $(p<0.05)$ than the side scatter (299.27 \pm 5.05$)$ and RGV (259.53 \pm 6.22 RSU) of the floating colonial cells. Moreover, the floating colonies showed a higher mean diameter-to-mean cell number per colony ratio $(0.26)$ than that $(0.14)$ of the sinking colonies. This value, along with micrograph in Fig. 4, indicates that the aggregation of algal cells in the floating colonies was looser than that of the sinking colonies.

\section{DISCUSSION}

Similar to other flagellates (e.g., Collodictyon triciliatum, Diphylleia rotans, and Poterioochromonas sp.) which have been reported in previous literature (Nishibe et al. 2002; Kim et al. 2006; Zhang et al. 2008), Ochromonas sp. exhibited a strong grazing ability on unicellular $M$. aeruginosa and high growth rate after grazing activaty in our experiment.

The hepatotoxic Microcystis strains are toxic to many potential grazers of Microcystis, which enable them to resist the grazing pressure from these zooplanktons (Demott et al. 1991; Jang et al. 2003). However, microcystins can not provide antiherbivore defense against mixotrophic flagellates (Wilken et al. 2010). Volume enlargement due to colony formation is the main mechanism of M. aeruginosa to resist the grazing pressure from Ochromonas sp. (Yang et al. 2009b). This defense mechanism entitled some of $M$.

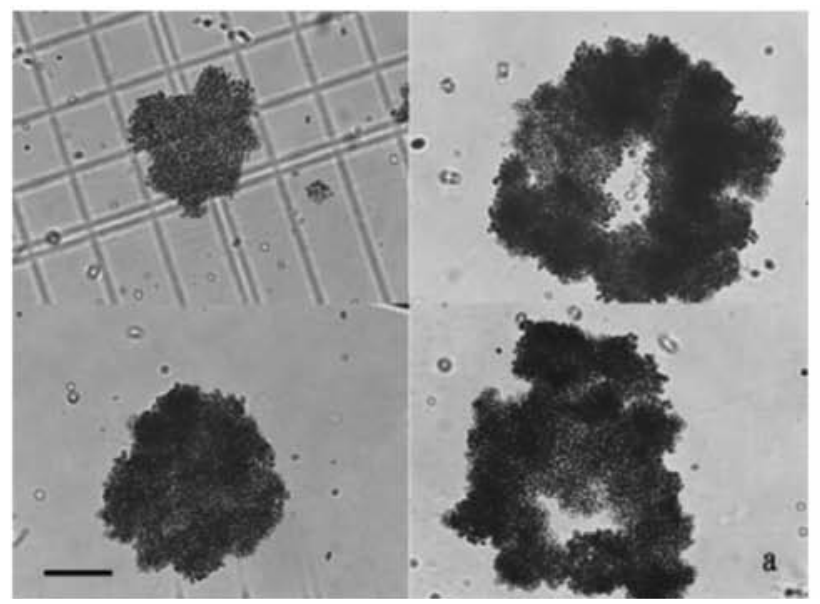

aeruginosa cells to survive in our co-cultivation system, even under strong grazing pressure. Due to the decrease in available food and growth space, growth of Ochromonas sp. became slower, and a cell concentration of approximately $1.0 \times 10^{6}$ cell $\mathrm{mL}^{-1}$ was maintained.

Two different mechanisms are involved in colony formation. The first mechanism is that colonies are formed when daughter cells of a freshly dividing cell fail to separate from mother cells during the reproductive process. The second mechanism involves the aggregation of already existing single cells or colonies (Lurling, and Van Donk 1997). Based on the continuous observation in our present experiment, the colony formation in $M$. aeruginosa was not emergent. Small colonies with several cells appeared on the $10^{\text {th }} \mathrm{d}$. These colonies evidently originated from the single cells which failed to separate during the cell division cycle. These undivided cells underwent multiple rounds of cell division that resulted in increased cell aggregation and eventually formed a colony. Therefore, the former mechanism describes the colony formation in $M$. aeruginosa. The in situ observation on colony formation and enlargement in $M$. aeruginosa from previous study in Taihu Lake also supports this mechanism (Cao, and Yang 2010).

Quantitative analysis of polysaccharide showed that colonial M. aeruginosa cells have higher EPS content compared with those of the unicellular cells. This finding is consistent to that of the previous studies on the biochemical composition of colonial and disaggregated $M$. aeruginosa cells in our laboratory (Zhang et al. 2007; Yang et al. 2008). EPS plays an important role on the conglutination of cells in colonial alga (De Philippis, and Vincenzini 1998; van Rijssel et al. 2000; Pajdak-Stos et al. 2001; Thornton 2002). The agglutinating ability of polysaccharides depends on their monosaccharide composition (Bahat-Samet et al. 2004). Our assay on mono-saccharides showed that there was no significant difference in the monosaccharide composition between unicellular and colonial M. aeruginosa. This result indicates that the enhancement of agglutination

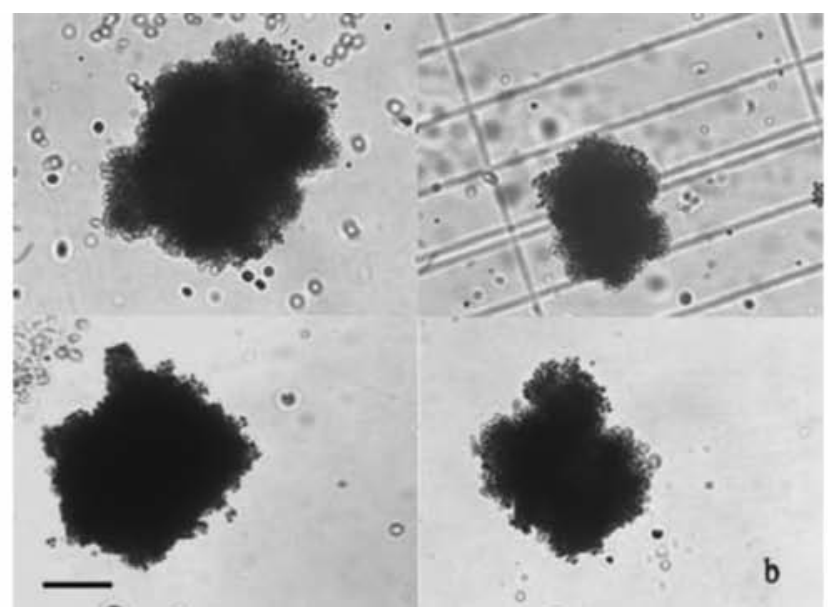

Fig. 4. Floating (a) and sinking (b) M. aeruginosa colonies induced by flagellate. Scale bars indicate $50 \mu \mathrm{m}$. 
between algal cells of colonial $M$. aeruginosa is attributable to the increase of total polysaccharide content, not the alteration of polysaccharide composition.

The ability of $M$. aeruginosa to dominate in an aquatic system can be attributed to gas vesicles to some extent, providing buoyancy and reducing sedimentation losses (Reynolds, and Walsby 1975). When an artificial culture with abundant nutrition and equal light is used for cultivation, unicellular $M$. aeruginosa may not need to regulate buoyancy by gas vesicles to obtain additional light or nutrition. Consequently, the RGV in unicellular $M$. aeruginosa decreases. By contrast, the nutrient uptake and light absorption by colonial cells would decrease based on the "package-effect" (Kirk 1994), which generally has an opposite effect to gas vesicle accumulation (Reynolds, and Walsby 1975; Deacon 1990; Brookes, and Ganf 2001). These phenomena may be the reasons for the enhancement of RGV in colonial cells. Furthermore, we also observed that the aggregation of algal cells in floating colonies is looser than that in sinking colonies, signifying a probable correlation between cell compactness and colony buoyancy.

Given that Ochromonas sp. usually co-exist with $M$. aeruginosa in natural lakes (Van Donk et al. 2009), the grazing pressure from Ochromonas sp. could also be an important trigger for colony formation in M. aeruginosa in natural freshwater system. In the present study, the size and morphology of graze-induced $M$. aeruginosa colonies are similar to those of naturally occurring colonies as shown in previous studies. However, mucilage, which retains the typical shape of $M$. aeruginosa colony in natural lakes (Brunberg 1999), did not form on the periphery of grazeinduced colonies. Thus mucilage formation probably requires other environmental factors, such as bacteria, light, and nutrients, to name a few.

Considering that the flagellate has a strong grazing ability on unicellular M. aeruginosa, Ochromonas sp. could be used as a potential biological control agent against Microcystis blooms (Zhang et al. 2008; Van Donk et al. 2009). However, for the phagotroph, prey size is an important selective factor for the grazing of Ochromonas who prefers food-size particles between 0.9 and $1.2 \mu \mathrm{m}$ (Zhang, and Watanabe 2001; Pfandl et al. 2004). In our studies, Ochromonas sp. showed an extremely low clearance rate on colonial $M$. aeruginosa, even for a small colony with 16 $\mu \mathrm{m}$ diameter (Yang et al. 2009b). In natural lakes, $M$. aeruginosa usually exists as a colony with a diameter of hundreds or even thousands micrometers. Therefore, additional studies are needed regarding the application of flagellate as a biocontrol agent against Microcystis blooms.

\section{CONCLUSIONS}

Flagellate Ochromonas sp. exhibits a strong grazing ability on unicellular $M$. aeruginosa. Under a continuous grazing pressure by Ochromonas sp., unicellular M. aerug- inosa could form a large colony with thousands of algal cells. EPS content and RGV of each cell increase significantly after colony formation. Based on the difference in morphology, as well as the mean diameter-to-mean cell number per colony ratio between floating and sinking colonies, a correlation probably exists between cell compactness and colony buoyancy.

\section{ACKNOWLEDGMENTS}

This work has been supported by State Key Fundamental Research and Development Program (2008CB418002) and the project of the Front Fields Program (CXNIGLAS200810).

\section{REFERENCES}

Bahat-Samet E, Castro-Sowinski S, and Okon Y. 2004. Arabinose content of extracellular polysaccharide plays a role in cell aggregation of Azospirillum brasilense. FEMS Microbiol. Lett. 237: 195-203.

Blom JF, Hornak K, Simek K, and Pernthaler J. 2010. Aggregate formation in a freshwater bacterial strain induced by growth state and conspecific chemical cues. Environ. Microbiol. 12: 2486-2495.

Bolch CJS, and Blackburn SI. 1996. Isolation and purification of Australian isolates of the toxic cyanobacterium Microcystis aeruginosa Kutz. J. Applied Phycol. 8: 5-13.

Brookes JD, and Ganf GG. 2001. Variations in the buoyancy response of Microcystis aeruginosa to nitrogen, phosphorus and light. J. Plankton Res. 23: 1399-1411.

Brunberg AK. 1999. Contribution of bacteria in the mucilage of Microcystis spp. (Cyanobacteria) to benthic and pelagic bacterial production in a hypereutrophic lake. FEMS Microbiol. Ecol. 29: 13-22.

Burkert U, Hyenstrand P, Drakare S, and Blomqvist P. 2001. Effects of the mixotrophic flagellate Ochromonas sp. on colony formation in M. aeruginosa. Aquat. Ecol. 35: 9-17.

Cao HS, and Yang Z. 2010. Variation in Colony Size of Microcystis aeruginosa in a Eutrophic Lake during Recruitment and Bloom Formation. J. Freshwater Ecol. 25(3): 331-335.

De Philippis R, and Vincenzini M. 1998. Exocellular polysaccharides from cyanobacteria and their possible applications. FEMS Microbiol. Rev. 22: 151-175.

Deacon CAEW. 1990. Gas vesicles formation in the dark, and in light of difference irradiances, by the cyanobacterium Microcystis sp. Brit. Phycol. J. 25: 133-139.

DeMott WR, Zhang QX, and Carmichael WW. 1991. Effects of toxic cyanobacteria and purified toxins on the survival and feeding of a copepod and 3 species of Daphnia. Limnol. Oceanogr. 36: 1346-1357.

Falconer IR. 1999. An overview of problems caused by toxic bluegreen algae (cyanobacteria) in drinking and recreational water. Environ. Toxicol. 14: 5-12.

Fulton RS, and Paerl HW. 1987. Toxic and inhibitory effects of the Blue-Green-Alga Microcystis aeruginosa on herbivorous zooplankton. J. Plankton Res. 9: 837-855.

Hahn MW, Lünsdorf H, and Janke L. 2004. Exopolymer production and microcolony formation play an important role in protistan grazing defense of novel bacterial strains isolated from 
freshwater plankton. Aquat. Microb. Ecol. 35: 297-308.

Hahn MW, Moore ERB, and Hofle MG. 2000. Role of microcolony formation in the protistan grazing defense of the aquatic bacterium Pseudomonas sp MWH1. Microbial Ecol.,39: 175-185.

Hessen DO, and Van Donk E. 1993. Morphological-changes in Scenedesmus induced by substances released from Daphnia. Arch. Hydrobiol. 127: 129-140.

Jang MH, Ha K, Joo GJ, and N.Takamura. 2003. Toxin production of cyanobacteria is increased by exposure to zoo-plankton. Freshwater Biol. 48: 1540-1550.

Kim BR, Nakan S, Kim BH, and Han MS. 2006. Grazing and growth of the heterotrophic flagellate Diphylleia rotans on the cyanobacterium Microcystis aeruginosa. Aquat. Microb. Ecol. 45: 163-170.

Kirk JTO. (Ed). 1994. Light and photosynthesis in aquatic systems. Cambridge University Press, Cambridge.

Lampert W, Rothhaupt KO, and Vonelert E. 1994. Chemical induction of colony formation in a Green-Alga Scenedes-musAcutus) by grazers (Daphnia). Limnol. Oceanogr. 39: 1543-1550.

Li T, Wu C, and Zhang Y. 1982. Studies of gas chromatographic analysis of saccharides and alditols: Some improvements in the analysis of acetylated aldononitriles by gas chromatography. Chinese J. Anal. Chem. 10: 272-276.

Lurling M. 2003a. The effect of substances from different zooplankton species and fish on the induction of defensive morphology in the green alga Scenedesmus obliquus. J. Plankton Res. 25: 979-989.

Lurling M. 2003b. Phenotypic plasticity in the green algae Desmodesmus and Scenedesmus with special reference to the induction of defensive morphology. Ann. Limnol.-Int. J. Lim. 39: $85-101$.

Lurling M, and Van Donk E. 1997. Morphological changes in Scenedesmus induced by infochemicals released in situ from zooplankton grazers. Limnol. Oceanogr. 42: 783-788.

Nishibe Y, Kawabata Z, and Nakano S. 2002. Grazing on Microcystis aeruginosa by the heterotrophic flagellate Collodictyon triciliatum in a hypertrophic pond. Aquat. Microb. Ecol. 29: 173-179.

Oliver RL. 1994. Floating and sinking in gas vacuolaterd cyanobacteria. J. Phycol. 30: 161-173.

Pajdak-Stos A, Fialkowska E, and Fyda J. 2001. Phormidium autumnale (Cyanobacteria) defense against three ciliate grazer species. Aquat. Microb. Ecol. 23: 237-244.

Pfandl K, Posch T, and Boenigk J. 2004. Unexpected effects of prey dimensions and morphologies on the size selective feeding by two bacterivorous flagellates (Ochromonas sp and Spumella sp.). J. Eukaryot. Microbiol. 51: 626-633.

Reynolds CS, Jaworski GHM, Cmiech HA, and Leedale GF. 1981. On the annual cycle of the Blue-Green-Alga Microcystis aeruginosa Kutz emend Elenkin. Philos. T. Roy. Soc. B. 293: 419-477.

Reynolds CS, and Walsby AE. 1975. Water-Blooms. Biol. Rev. 50: 437-481.

Rippka R, Deruelles J, Waterbury JB, Herdman M, and Stanier RY. 1979. Generic Assignments, Strain Histories and Properties of Pure Cultures of Cyanobacteria. J. Gen. Microbiol. 111: $1-61$.

Thornton DCO. 2002. Diatom aggregation in the sea: mechanisms and ecological implications. Eur. J. Phycol. 37: 149-161.

Van Donk E, Cerbin S, Wilken S, Helmsing NR, Ptacnik R, and Verschoor AM. 2009. The effect of a mixotrophic chrysophyte on toxic and colony-forming cyanobacteria. Freshwater Biol. 54: $1843-1855$.

van Gremberghe,I, Vanormelingen P, Van der Guch K, Mancheva A, D'hondt S, De Meester L, and Vyverman W. 2009. Influence of Daphnia infochemicals on functional traits of Microcystis strains (Cyanobacteria). Hydrobiologia 635: 147-155.

van Rijssel M, Janse I, Noordkamp DJB, and Gieskes WWC. 2000. An inventory of factors that affect polysaccharide production by Phaeocystis globosa. J. Sea Res. 43: 297-306.

von Elert E, and Franck A. 1999. Colony formation in Scenedesmus: grazer-mediated release and chemical features of the infochemical. J. Plankton Res. 21: 789-804.

Wilken SWS, Huisman J, and Van Donk E. 2010. Microcystins do not provide anti-herbivore defence against mixotrophic flagellates. Aquat. Microb. Ecol. 59: 207-216.

Wu ZX, and Song LR. 2008. Physiological comparison between colonial and unicellular forms of Microcystis aeruginosa Kutz. (Cyanobacteria). Phycologia 47: 98-104.

Yang Z, Kong FX, Shi XL, and Cao HS. 2006. Morphological response of Microcystis aeruginosa to grazing by different sorts of zooplankton. Hydrobiologia 563: 225-230.

Yang Z, Kong FX, Shi XL, Zhang M, Xing P, and Cao HS. 2008. Changes in the morphology and polysaccharide content of Microcystis aeruginosa (Cyanobacteria) during flagellate grazing. J. Phycol. 44: 716-720.

Yang Z, Kong FX, Yang Z, Zhang M, Yu Y, and Qian SQ. 2009a. Benefits and costs of the grazer-induced colony formation in Microcystis aeruginosa. Ann. Limnol.-Int. J. Lim. 45: 203208.

Yang Z, Kong FX, Zhang M, Yang Z, Yu Y, and Qian SQ. 2009b. Effect of filtered cultures of flagellate Ochromonas sp on colony formation in Microcystis aeruginosa. Int. Rev. Hydrobiol. 94: 143-152.

Ye WJ., Liu XL, Tan J, Li DT, and Yang H. 2009. Diversity and dynamics of microcystin-Producing cyanobacteria in China's third largest lake, Lake Taihu. Harmful Algae 8: 637-644.

Zhang M, Kong FX, Tan X, Yang Z, Cao HS, and Xing P. 2007. Biochemical, morphological, and genetic variations in Microcystis aeruginosa due to colony disaggregation. World J. Microb. Biot. 23: 663-670.

Zhang X, Hu HY, Hong Y, and Yang J. 2008. Isolation of a Poterioochromonas capable of feeding on Microcystis aeruginosa and degrading microcystin-LR. FEMS Microbiol. Lett. 288: 241-246.

Zhang XJ, Chen C, Lin PF, Hou AX, Niu ZB, and Wang J. 2011. Emergency Drinking Water Treatment during Source Water Pollution Accidents in China: Origin Analysis, Framework and Technologies. Environ. Sci. Technol. 45: 161-167.

Zhang XM, and Watanabe MM. 2001. Grazing and growth of the mixotrophic chrysomonad Poterioochromonas malhamensis (Chrysophyceae) feeding on algae. J. Phycol. 37: 738-743. 